\title{
Lo negro y la negritud en las tradiciones de Palma
}

\author{
Juan Carlos Adriazola Silva \\ Universidad Nacional de Piura, Piura - Perú \\ adriazola46@yahoo.es
}

\section{Resumen}

El tema de la cultura negra en el Perú es vasto y complejo, el aporte que ella ha dado a nuestro mestizaje no solo se circunscribe a lo biológico o racial, sino que tiene cotas altas y significativas que han marcado indeleblemente a toda la cultura peruana, razón por la cual no se le puede soslayar o dejar de reconocer bajo ninguna circunstancia. Para tener un panorama mayor del tema, es necesario asimismo adentrarse en los antecedentes remotos de la esclavitud negra en el Perú. El mencionado panorama ayudará también a entender mejor las tradiciones en las que don Ricardo Palma aborda los asuntos referidos a "lo negro" y "la negritud". Debe ponerse de relieve que para Palma estos temas no son ajenos en razón de su vinculación sanguínea con la raza negra.

Palabras clave: Tradición, lo negro, la negritud, esclavitud negra en Perú, afrodescendientes, afroperuano.

\section{Abstract}

The topic of black culture in Peru is extensive and complex. The contribution it has given to our miscegenation is not only confined to the biological or racial, but has also high and significant levels that have indelibly marked the entire Peruvian culture, and this is the reason why it cannot be ignored or failed to recognize under any circumstances. To have a bigger picture of the subject, an insight into the background of black slavery in Peru is needed. The aforementioned picture will also help to understand better the Peruvian Traditions in which Don Ricardo Palma addresses the issues referred to "the Negro" and "the Negritude". It should be emphasized that for Palma these issues are not unrelated because of their blood relationship with the black race.

Keywords: Tradition, the Negro, the Negritude, black slavery in Peru, Afrodescendant, Afro-Peruvian. 
Juan Carlos Adriazola Silva, Doctor en Educación por la Universidad Nacional de Piura. Magíster en Investigación y Docencia por la Universidad Nacional Pedro Ruiz Gallo de Lambayeque. Periodista por la Universidad de Piura. Diplomado en Relaciones Internacionales por la Academia Diplomática del Perú. Miembro del Instituto de Estudios Histórico Marítimos del Perú, Centro de Estudios Histórico Militares e Instituto Libertador Ramón Castilla, entre otros. 


\section{Cuestión previa: aclarar frases}

Una lectura superficial de las frases "lo negro" y "la negritud" podría llevar a pensar a muchas personas que ambas expresiones significan lo mismo, en el sentido de que refieren a "algo o alguien vinculado con la raza negra". Sin embargo, se ha encontrado una literatura frondosa respecto a dichas frases, lo que abre una serie de variados significados y connotaciones en el campo sociológico, antropológico, etnológico, lingüístico, político, filosófico y literario ${ }^{1}$. No es el propósito de esta investigación

l Por ejemplo, Marcos Govea y Marielvis Silva (2018) nos dicen que la negritud fue un concepto cultural y político surgido de la reacción contra la opresión del sistema colonial y el racismo reinante en las sociedades oprimidas por occidente. La negritud fue un movimiento de resistencia y de liberación, no solo porque designó un movimiento de escritura literaria de África negra, sino porque también se presenta como lucha, resistencia. Fue un movimiento, en contra de la consideración del negro como ser inferior o dependiente; es decir, fue una estrategia para revalorizar, apreciar y ponderar todas las características que se consideran como propias de la cultura negra y que pueden oponerse a los estereotipos europeos. Los primeros atisbos de la reflexión académica de la negritud aparecieron en Norteamérica hacia 1865, cuando después de la Guerra de Secesión, aparecen alrededor de cien universidades en Estados Unidos (Vallejo, 2013, pp. 4-5). Más tarde, en 1931, unos escritores norteamericanos del llamado "Renacimiento Negro" de Harlem, tales como Langston Hughes, Claude Mac Kay, Countee Gullen, Jean Toomer, Stirling Brown, publicaron en París, en traducción del inglés al francés, la Revista Mundo Negro, donde introdujeron en la literatura los conceptos de dignidad del hombre negro, belleza y reafirmación en el origen africano común. Vale destacar que el concepto francés de La Négritude se suma también a la reflexión dialéctica de Jean Paul Sartre, cuando este escribe el prólogo a la Anthologie de la nouvelle poésie nègre et malgache de langue française (1948), una antología elaborada por Leopoldo Sedar Senghor. En aquel, Sartre consideraba que la negritud era la toma de conciencia de los negros, la cual se iniciaba con la aceptación de su color, pues era a partir de este que se les oprimía. Para Sartre, la negritud era reconocer esa cierta cualidad común del pensamiento y las conductas de los negros, de tipo esencialista, en donde por antítesis dialéctica, se oponía a la tesis de la superioridad del blanco. La síntesis sería entonces la sociedad sin racismo. Sin embargo, la antítesis de la tesis racista, podía ser calificada de "racismo antirracista". El concepto negritud caló hondo en autores de otras latitudes, tal es el caso de Aimé Césaire, Martin Robinson Delany, Edward 
adentrarse en esos espinosos campos de las conceptualizaciones, o determinar quiénes son los preconizadores o detractores de cada una de ellas. Simplificamos la cuestión indicando solamente que en este ensayo se entiende por "lo negro" al conjunto de características o rasgos psicológicos que presenta comúnmente la gente de raza negra en su desenvolvimiento social y cultural, lo cual ha llevado a personas de razas diferentes a conceptualizarla de un modo determinado, vale mencionar que este no siempre ha sido justo o equilibrado, sino más bien cargado de fuertes prejuicios. Así, por ejemplo, se han considerado tradicionalmente como características o rasgos psicológicos de los negros la indolencia, la pereza, la rebeldía, la socarronería ${ }^{2}$, el comportamiento festivo, la superstición, la hilaridad ruidosa, la actitud pretensiosa, la terquedad, la sensualidad, el poco intelectualismo ${ }^{3}$, etc.

Wilmot Blyden y William Edward Burghardt Dubois, así como en los escritores haitianos Anténor Firmir y Jean Price-Mars y el jamaiquino William Makey. En el caso del Perú, M’Bare N'Gom, siguiendo la línea de la revalorización de los autores que han hecho de la negritud una bandera de reivindicación social a través de la literatura, ha organizado una serie de actividades académicas sobre dicho tema. Asimismo, ha publicado diversos libros y artículos tanto de su autoría como en forma de compilación de otros autores. Por ejemplo: "Escribir" la identidad: creación cultural y negritud en el Perú. Lima, Editorial Universitaria de la Universidad Ricardo, Palma, 2008.

2 Según José Antonio del Busto, "la socarronería -una de las viejas características del negro peruano- se ha difundido como la astucia o disimulo acompañado de burla encubierta. Este sentido del humor en los negros criollos marcha ligado a su realidad física y fonética" (2014, p. 72).

3 Estos conceptos negativos o peyorativos siempre estuvieron presentes a lo largo de la historia de los negros en el Perú. Sin embargo, recién a fines del siglo XIX, con la llegada del Positivismo, se trataron como asunto o materia académica en la Universidad Nacional Mayor de San Marcos. Uno de sus primeros abanderados fue el Dr. Javier Prado Ugarteche (Quiroz, 2010, pp. 27-33). Las ideas positivistas tuvieron eco en muchos de sus discípulos, justamente uno de ellos será Clemente Palma -hijo del tradicionalista-, quien se graduó en 1897 como bachiller en la Facultad Letras con la tesis El porvenir de las razas en el Perú. En ella, refiriéndose específicamente a la raza negra, dice: "El negro ha tenido un campo muy estrecho para las lucubraciones mentales. En él no ha habido desgaste de fuerza nerviosa; de modo que, si hubiera sido una raza intelectual, habría sabido domar la 
En cuanto a "la negritud", esta frase tiene para nosotros un significado particular con sentido global, en tanto hace referencia exclusiva a los melanodermos o gente de piel negra de los diversos pueblos o comunidades nativas $u$ oriundas del África; y, por extensión, a todas sus descendencias que los han prolongado en el tiempo y en el espacio. Por esta razón, pertenecen a la negritud: 1) Las poblaciones de los diferentes reinos tribales que florecieron en la costa africana occidental (actuales países de Senegal, Guinea, Costa de Marfil, Ghana, Dahomey, Nigeria, Camerún, Gabón, Congo, Angola) y en las islas que estaban frente al continente negro en el Océano Atlántico (Cabo Verde, São Tomé e Príncipe); 2) Las poblaciones asentadas en la costa africana oriental (Somalia, Kenya, Tanzania, Mozambique, Sudáfrica) y su mayor y más importante isla en el Océano Índico, Madagascar; 3) Las poblaciones del norte, centro y noreste (Argelia, Libia, Egipto, República Centroafricana, Uganda, Zambia, Chad, Sudán, etc.). Las naciones o castas que, desde tiempos remotos, conformaron la base étnica de todos estos actuales países, suman, según Juan Mariátegui, más de medio centenar (1990, p. 147).

De esas naciones o castas africanas llegaron al Perú, de acuerdo a diversos documentos históricos de archivo, guineos, congos,

naturaleza, transformarla y hacerla dócil en la satisfacción de sus necesidades. (...) Es una raza inferior, pero no una raza decrépita, como la raza india. (...) En lo que se refiere a su carácter, el negro es fiel, es sociable y fanático; al mismo tiempo es cobarde, rencoroso y sin energía. En la raza negra hay un elemento de degeneración que si no ha producido sus efectos es por la naturaleza misma de su vida salvaje, que tonifica su organismo, y por la inactividad de su vida mental. Ese elemento es la sensualidad, la lujuria desmedida de esta raza, que tiene en su sangre los ardores del sol que calcina los desiertos. (...) Hay en él una conciencia honda de su inferioridad moral y psíquica con respecto al blanco; y ello motiva la envidia que le profesa, el odio agudo que le tortura, y al cual da salida siempre que la ocasión le favorece. (...). En resumen, la raza negra es una raza inferior porque no reúne las condiciones de intelectualidad y carácter que la sociología asigna á las razas perfectibles y predispuestas para construir una nacionalidad próspera" (Palma, 1897, pp. 21-23). 
angolas, locumés(llamadostambiényorubasonagos), terranovos, mandingas (o malinkés), cambundas, carabalíes, chalas, cabindas, jalofes (jalofos), huaracharíes, mirangas, aubundas, cafres (hotentotes/bosquimanos), ashantis (o ashantes), brams (o brans), bañoles, ararás, nalús, banguelas, minas, santomés, mozambiques y tanganicos (Busto, 2014, p. 31). A todos los negros nacidos en África se les decía corrientemente negros de nación, en contraposición a los negros criollos, nacidos en el Nuevo Mundo. Luego a estas progenies se les ha llamado de forma conjunta como africanías ${ }^{4}$ y, en las últimas décadas, se les conoce en los estudios sociales como afrodescendencias ${ }^{5}$, las cuales, según el continente o el país donde se desarrollan y ubican en el presente se les denomina de forma específica o particular como afroamericanos, afrocaribeños, afroperuanos ${ }^{6}$, afrocolombianos, afroecuatorianos, afrocubanos, etc.

4 Uno de los primeros estudiosos en usar este término fue el lingüista, etnólogo y antropólogo cubano Fernando Ortiz Fernández, quien lo utiliza en su conocida obra La africanía de la música folklórica de Cuba (1950).

5 El tema de las afrodescendencias tomó gran importancia a partir de que la ONU declaró el 23 de diciembre del 2013 que el período 2015-2024 sería denominado como el "Decenio Internacional de los Afrodescendientes. Reconocimiento, Justicia y Desarrollo”. Lo que busca esta Declaración y Programa es la no discriminación y la igualdad ante la ley que merece la gente de raza negra, como principios fundamentales de las normas internacionales de derechos humanos (Ministerio de Cultura, 2016, p. 90).

6 Para un desarrollo más amplio de los afroperuanos, puede verse la investigación de Humberto Rodríguez Pastor (2008) Negritud. Afroperuanos: resistencia y existencia. (Serie Mano Negra / 1), Lima: Centro de Desarrollo Étnico (CEDET); Martín Benavides, Juan León, Lucía Espezúa y Alejandro Wangeman (2015) Estudio especializado sobre población afroperuana, Lima: Ministerio de Cultura del Perú y Grupo de Análisis para el Desarrollo. Por otra parte, es importante señalar que actualmente existe en el Perú un Día de la Cultura Afroperuana, el mismo que se celebra el 4 de junio de cada año, según fue decretado por el Congreso de la República, en homenaje a la fecha de nacimiento de Nicomedes Santa Cruz Gamarra (1925), un notable descendiente de la negritud que promovió infatigablemente toda su vida los valores de la cultura negra desde 1956. 


\section{Condición de los negros esclavos en la península ibérica}

En 1442, esto es medio siglo antes de que Cristóbal Colón llegara a las Indias, eran introducidos en la península ibérica diez negros, capturados en las costas de Guinea (Río del Oro) por el explorador portugués Antón Gonçalves (Santa Cruz, 1988, p. 7), con lo cual se abrió uno de los comercios más infames y execrables de la historia humana: la esclavitud de los negros ${ }^{7}$. Historiadores como Miguel del Rey y Carlos Canales coinciden en afirmar que fue el infante de Portugal Enrique el Navegante quien intensificó este tipo de comercio en esa parte occidental de Europa, con el propósito de tener mano de obra barata en plantaciones, minas o para servir en trabajos domésticos (2014, p. 13). Comercio que floreció significativamente con la aparición de las primeras compañías lusitanas especializadas en el tráfico negrero, las cuales obtenían esclavos de sus factorías costeras (Islas de Cabo Verde y São Jorge de la Mina) y de tierra adentro del continente africano, lugares desde donde se les llevaba a Portugal y España como cosas, pues hablando en términos jurídicos de la época, el esclavo era un objeto real. Por lo tanto, se les podía comprar, vender, alquilar, depositar, hipotecar, prestar, dar en prenda o regalar. Además, de enajenable, era embargable y confiscable (Busto, 2014, p. 28). Corrobora este aserto Antonio

7 La esclavitud era una institución con tradición en Europa desde la Edad Antigua, y nació como una alternativa de usar a los cautivos de guerra, en vez de sacrificarlos. Con ello se da a entender que hubo también esclavos blancos que estuvieron en esta condición. Por otra parte, mucho antes del siglo XV, el comercio de esclavos a través de las rutas transaharianas para abastecer los mercados europeos o de Oriente Medio, había sido una parte tradicional de la forma de vida africana. Una magnífica fuente de ingresos tanto para los estados islámicos como para los reinos tribales de la propia África. Cuando a partir del siglo XV ambas razones se unieron al interés de los europeos, que necesitaban mano de obra barata para extenderse por nuevos territorios de los que obtener riquezas, todo cambió: los esclavos pasaron a ser, única y exclusivamente un objeto dependiente de factores económicos (Rey y Canales, 2014, p. 13). 
Domínguez Ortiz (1984), cuando dice que, sobre los esclavos negros, "auténticos marginados", pesaba una triple carga: la primera de ellas era una carga legal, porque carecían de libertad y personalidad jurídica; luego una carga racial, porque al igual que los turcos, en ese momento los negros eran considerados escoria social; y la tercera, una carga religiosa, ya que su credo de origen era el mahometismo o la idolatría (Santa Cruz, 1988, p. 8)

Con el tiempo, a los negros no les quedó otro camino para liberarse de esas cargas que emblanquecer su piel a través de uniones sucesivas con gente de otras razas. Es así como surgen las conocidas "tablas del mestizaje", que se van creando a partir de las nuevas uniones de sangre. El historiador Julio Caro Baroja recuerda cómo en el antiguo Museo Antropológico de Madrid vio diversos cuadros pintados al óleo procedentes del Perú del siglo XVIII ${ }^{8}$, en donde se explicaba al público, a través de series pictóricas, los diversos cruzamientos raciales. El mensaje prejuicioso que subyacía en ellos era que, a mayor carga de sangre blanca o europea, más civilización y más riqueza. La introducción del elemento negro solo producía estancamiento o descenso social. Los productos raciales clasificados entonces eran los siguientes:

- Negro y negra bozal produce negro.

- Español (entiéndase blanco europeo) y negra de Guinea o criolla produce mulato.

- Mulato y mulata producen mulato o mulata.

- Español y mulata producen cuarterón de mulato.

8 De acuerdo a lo investigado por Ricardo Kusonoki (2016, p. 33), estas series pictóricas de las diversas combinaciones raciales que se dieron en América, se atribuyen al pintor Cristóbal Lozano (1705-1776). Todo apunta a que le fueron solicitadas por el virrey Manuel Amat y Juniet (circa 1771) como una forma didáctica de visualizar sobre todo la degeneración que sufre la raza blanca o española al combinarse con la raza negra y otras inferiores. 
- Español y cuarterona de mulato producen quinterón o quinterona de mulato.

- Español y quinterona de mulato producen requinterón o requinterona de mulato.

- Español y requinterona de mulato producen "gente blanca".

- Español y gente blanca producen "casi limpios de su origen".

- Español e india serrana y civilizada producen mestizo.

- Mestizo con indio producen cholo.

- Mulato e india producen chino.

- Español y china producen cuarterón de chino.

- Negro e india producen zambo de chino.

- Negro y mulata producen zambo. (Caro, 1967, pp. 5-7)

\section{Los negros en el Nuevo Mundo}

La aparición del negro al lado de los europeos descubridores y conquistadores del Nuevo Mundo ha sido causa de desconcierto en no pocos historiadores y ensayistas contemporáneos; al punto que los designan con un contradictorio nombre de esclavosconquistadores (Mellafe, 1964, p. 26), que peca de paradojal en su misma antinomia. Estos negros no son otros que los mismos negros ladinos, que devinieron en "aliados" o "auxiliares" de los castellanos que dieron inicio a la empresa quinientista.

En la historia del Perú se cuenta que uno de los trece de la Isla del Gallo fue un negro ladino, que desembarcó luego en Tumbes. Este negro debió ser el mismo africano asistente del maestro artillero Pedro de Candia en la expedición de conquista de 1531, hombre tan respetado que mereció llevar el título de capitán, hasta que el amago del partidismo de las guerras civiles causó su muerte a manos de la facción de Pizarro. Pasados estos hechos, diversas oleadas de negros bozales fueron llegando a América 
en mayor cantidad desde la Península ${ }^{9}$, primero, ingresando a través de los principales puertos negreros que se instauraron en el siglo XVI y XVII como son Cartagena de Indias, Veracruz y Buenos Aires; y, segundo, mediante otros puertos menores en la región como Cuba, Santo Domingo, Río de la Hacha, Honduras, Portobello y Tierra Firme (Peralta, 1990, p. 156). De esos puertos podían reembarcarse inmediatamente a negros bozales a otros destinos de la América española; en otros casos, se esperaba algunos años para que sean más bien los hijos de los negros bozales, los llamados negros criollos, los que fueran comercializados en el mercado negrero americano.

La terminología del tráfico negrero daba el nombre genérico de "pieza" a cada unidad de la "cargazón". Como lo ha recordado bien el doctor José Antonio del Busto, eufemísticamente se decía también a esas unidades de negros "piezas de ébano", para distinguirlas de otras piezas, como la "de bambú" (cuando se trataba de chinos y japoneses), la "de carey" (cuando eran malabares originarios de Goa y Calicut), o la "de marfil" (cuando eran moriscos, berberiscos o bereberes). Pero llegado el cargamento humano a su destino, se hacía con él una selección rigurosa atendiendo los criterios de edad, salud y contextura de cada pieza (2014, p. 25).

\section{La esclavitud negra en el Perú}

La esclavitud es una institución traída por los españoles al Perú. De tal modo que no debe extrañar que así como había esclavos negros los había también blancos (Hart-Terré, 1973, p. 124).

9 De acuerdo con el estudio de Germán Peralta Rivera, los diferentes navíos, naos, zafras, carabelas, fragatas, filibotes, urcas y pataches con cargamentos de negros africanos llegaron a la Península mediante los puertos de Canarias, Lisboa, Sevilla, San Lúcar de Barrameda y Cádiz, y desde ahí partían luego a los puertos americanos más importantes (1990, pp. 200 y 298) 
Con relación a los emporios negreros más tempranos de la época virreinal, los encontramos en los extremos de la Ciudad de los Reyes (Lima), en la Villa de Santiago de Miraflores de Saña (Lambayeque) y en la Villa de Santa María de Cañete y en Chincha (Ica). En otros lugares de la costa peruana la presencia de la negritud se hallaba focalizada en puntos determinados, tal es el caso de San Miguel de Piura, en donde cientos de esclavos negros poblaban la hacienda Yapatera, la misma que en el futuro daría origen al actual pueblo negro del mismo nombre.

Cuando los negros llegaban a Lima y eran comprados por sus amos, el primer cuidado que estos ponían era bautizarlos para hacerlos católicos; todos ellos se volvían, pues, devotos de la Virgen del Carmen o de la del Rosario; y se reunían después por naciones o castas en cofradías para ocuparse de los asuntos del culto y otros no menos graves. En la capital peruana hubo cofradía de terranovos, lucumís, mandingas, cabundas, carabalíes, cangaes, chalas, huaracharíes, congos y misangas. Todas estas naciones o castas estaban sujetas a dos caporales mayores que ellos mismos elegían, los cuales se mantenían en el goce del empleo hasta que morían. En el resto de ciudades del Perú se siguió el mismo modelo y ello pervivió incluso hasta bien entrada la República.

Con la proclamación de la Independencia el 28 de julio de 1821 , las condiciones sociales de los esclavos negros no variaron mucho con respecto al antiguo régimen. Asimismo, continuó prevaleciendo la diferencia entre los esclavos que trabajaban en espacios urbanos y en espacios rurales. Desde la ropa que vestían se notaba esta diferencia, ya que si en el campo solían usar tocuyos sencillos, en la ciudad se veía a algunos esclavos vestidos a la manera occidental e incluso con cierta elegancia. Por otra parte, en la ciudad, cualquier persona que quisiera darse tono frente a los de su clase debía, por lo menos, tener un esclavo negro a su servicio. En la ciudad no todos los habitantes 
poseían grandes propiedades. Por ello, para recuperar su inversión, muchas veces los amos enviaban a sus esclavos a realizar jornadas laborales para otros empleadores, que les pagaban una cantidad semanal. De este ingreso económico, el esclavo negro recibía una ínfima parte.

Hito importante en la historia de los negros en el Perú es el decreto dado en la ciudad de Huancayo el 5 de diciembre de 1854 por orden del presidente Ramón Castilla ${ }^{10}$. Según José Antonio del Busto, el último traficante de negros sería Domingo Elías entre 1850 y 1854 (2014, p. 71). De este modo, el Perú se adelantaría a su tiempo y a otras naciones más desarrolladas como los Estados Unidos de América que recién abolirían la esclavitud negra en 1865, en época del presidente Abraham Lincoln. Entre 1854 y 1860 se manumitieron 25.505 negros esclavos, lo que significó que el Estado peruano indemnizara a sus amos con 7'651.500 pesos. Desde entonces la vida de los negros empezó a cambiar muy lentamente. Su impronta en el mestizaje peruano es innegable, pero quizá sean sus aportes a la música, a la danza y a la gastronomía ${ }^{11}$ los más conocidos (Busto, 1993, pp. 25-29; 36-40). No menos importantes han

10 Manuel Saponara ha precisado que el primer intento de abolición de la esclavitud en el Perú lo dio el general don José de San Martín cuando dictó el decreto de "Libertad de Vientres" (el principio era: "nadie nace esclavo en el Perú”) el 12 de agosto de 1821 (2008, p. XV).

11 En el aporte gastronómico, cabe destacar el papel que han jugado los vendedores ambulantes en calles y plazas limeñas desde la época virreinal. Algunos antiguos alimentos dulces y salados de origen negro han llegado a convertirse hoy en platos y bebidas emblemáticas de nuestra gastronomía nacional. Tal es el caso de la mazamorra morada, el champús, el zanguito de ñajú, el ranfañote, los frejoles colados, los picarones, los anticuchos, los choncholíes, la chicha morada, la chicha de piña, etc. Gracias a los grabados de Manuel Atanasio Fuentes publicados en su obra Lima. Apuntes históricos, descriptivos, estadísticos y de costumbres (París, 1867), así como a Carlos Prince con su primera serie de Lima Antigua. Tipos de antaño con numerosas viñetas (Lima, 1890), tenemos imágenes de los vendedores ambulantes tal cual como los menciona don Ricardo Palma en sus Tradiciones. 
sido sus contribuciones al campo lingüístico y lexicográfico de nuestra cultura (Romero, 1987, pp. 149-170; Holguín, 2001, pp. 135-136).

Como bien ha señalado Del Busto Duthurburu, para entender la historia de los negros en el Perú es necesario verla como un largo proceso bifacial, esto es, hay en ella siempre dos caras inseparables, pero importantes. Es una historia triste y festiva, sumisa y rebelde, opaca y colorida, silente y bullangera, santa y pecadora, oscura y luminosa, infortunada y feliz (2014, p. 119). Es una historia que, además, nos debe interesar a todos los peruanos, porque la inmensa mayoría de gente tenemos de todas las sangres, pues como dice el refrán: "El que no tiene de inga tiene de mandinga". Refrán este que, dicho sea de paso, Augusto Alcocer Martínez ha demostrado documentalmente no es de la autoría de Ricardo Palma ${ }^{12}$, como muchas veces se ha creído.

\section{¿Desciende Ricardo Palma de la raza negra?}

El más connotado biógrafo del tradicionista, Oswaldo Holguín Callo, en la hasta ahora insuperada obra Tiempos de Infancia y de Bohemia. Ricardo Palma (1833-1860), luego de hacer un análisis meticuloso de una serie de documentos de primera mano, llega a afirmar categóricamente que el Padre de las Tradiciones:

12 Por largo tiempo se ha atribuido a don Ricardo Palma la frase: "El que no tiene de inga tiene de mandinga”. Sin embargo, el acucioso lingüista sanmarquino Augusto Alcocer Martínez ha demostrado documentalmente que la mencionada frase era ya utilizada muchos años antes de escribirse las Tradiciones peruanas. De este modo, corrige un error repetido por muchos lexicógrafos, biógrafos, estudiosos palmistas, historiadores, como Roberto Mc Lean y Estenós, Denys Cuche, Franklin Pease G. Y., Oswaldo Holguín, entre otros, quienes llegaron a afirmar en su momento que Palma era el autor de la frase en cuestión (v. Alcocer, 2004, p. 34). 
Nació en Lima el jueves 7 de febrero de 1833 como fruto de la unión libre, más tarde legitimada, de Pedro Palma y Dominga Soriano, jóvenes provincianos a quienes la capital peruana había convocado para ser los progenitores de uno de sus hijos más notables. Pedro era quince años mayor que Dominga, quien solo contaba dieciséis y, por ende, estaba muy lejos de la mayoría de edad (1994, pp. 22-23).

¿Quiénes fueron estos jóvenes progenitores? Sobre el particular, el documento que en parte da respuesta a esta pregunta es la partida de bautismo del propio Manuel Palma ${ }^{13}$, la cual fue publicada de modo facsimilar por Julio Díaz Falconí en 1991 como carátula de la primera edición de Tradiciones Olvidadas de Palma. En ella se lee:

En la ciudad de Lima capital de la República del Perú, en once de febrero de mil ochocientos treinta y tres: el presbítero D. Manuel Almirón teniente de los curas rectores del Sagrario de la Catedral exorcizó, puso óleo y crisma á Manuel, de cinco días, á quien baitisó (sic) en caso de necesidad el S. Cura D. Mariano Santos: hijo natural de Pedro Palma, y de Guillerma Carrillo, Pardos: fue su padrino D. Martin Concha. Testigos D. Carlos Efen y Jorge Paz de lo cual Certifico. José María Guerci [Firmado].

Del texto de este documento, se desprende información que es interesante analizar. La primera que habría que resaltar es que el nombre de la madre del bautizado no corresponde con la realidad. Acerca de ello, Díaz Falconí ha enfatizado lo siguiente:

13 El nombre original del tradicionista es Manuel Palma. Según ha señalado José Miguel Oviedo, el escritor se lo cambió a los 15 años cuando se iniciaba en el periodismo combativo. "El 'Manuel' con que fue bautizado no debía, pues, gustarle mucho. Primero, tímidamente usaba los dos en conjunto y firmaba 'Manuel Ricardo Palma'; con el tiempo y con la fama, se olvidará de su verdadero nombre y será Ricardo para todos” (1965, p. 29). 
Como Dominga Soriano era menor de edad, no acudió a la parroquia del Sagrario de la Catedral a declarar el nacimiento de su hijo Manuel. Acudió la abuela: Guillerma Carrillo. Y por eso, en la partida de bautizo aparece el nombre de la abuela; y no de la madre. Esto acontece hasta ahora cuando las hijas menores tienen hijos. La abuela los declara como suyos. Y los cría como tales (2007, p. 13).

Un segundo dato que, para efecto de esta investigación, es necesario relievar en la partida de bautismo del tradicionista hace referencia a la condición racial de los padres. Cuando señala que son "Pardos". "Pardo" era un término eufemístico que se usaba en buena parte de América hispana desde el siglo XVII y continuó utilizándose en la época decimonónica para referirse al "negro". Obviamente no a los negros retintos ${ }^{14}$, sino al "mulato" (Hildebrandt, 2001, p. 531), que estaba en proceso de blanqueamiento por causas de la intervención biológica del mestizaje. De este modo, calificar a alguien de "pardo" era lo mismo que llamarlo "mulato", esto es, al nacido de negra y blanco o lo contrario. (DA, 2010, p. 1602).

Esta calificación de "Pardos" dada a los padres del bautizado, aparte de tener una connotación despectiva lleva a una confusión. La primera aclaración es que, al no asistir personalmente la madre del niño al acto bautismal, el calificativo de "pardo" (o “mulata") no le correspondería a Dominga Soriano sino más bien a la abuela Guillerma Carrillo (o Santa María) ${ }^{15}$.

14 El Diccionario de Americanismos (DA), en su cuarta acepción indica que la voz "retinto, -a" está referida a una persona de raza negra, de color muy intenso (Cfr. Asociación de Academias de la Lengua Española, 2010, p. 1865). Asimismo, cuando en el lenguaje coloquial se hablaba de los negros retintos, por lo general, se hacía mención a los negros "bozales" o nacidos en el continente africano, es decir, a los verdaderos negros o negros puros.

15 De acuerdo con diversos documentos estudiados por Oswaldo Holguín Callo, la mencionada abuela del tradicionista usó los dos apellidos de forma indistinta. Ello puede verificarse en la partida de bautismo de Ricardo Palma (1833), la 
Por otra parte, como bien ha señalado Díaz Falconí, después de analizar los diversos documentos que recoge el expediente matrimonial de los padres de don Ricardo Palma (tramitado en el año 1837 ante el Provisor y Vicario General de la Parroquia del Sagrario de Lima), no queda duda alguna que el padre del tradicionista fue en realidad mestizo y no "pardo" (o "mulato"). $\mathrm{Al}$ respecto se lee con claridad:

Pedro Palma, mestizo de edad de treinta y cinco años, natural de Cajabamba, provincia de Huamachuco, residente en esta ciudad diez años, hijo legítimo de Juan de Dios Palma, difunto, y de Manuela Castañeda, conforme a derecho ante Vuestra Señoría paresco y digo: Que tengo tratado contraer matrimonio según orden de Nuestra Santa Madre Yglesia (sic) con Dominga Soriano de edad veinte años, quarterona libre, natural de la villa de Cañete, residente en esta ciudad diez años, hija natural de Tomas Soriano, difunto, y de Guillerma Santa María (2015, p. 307).

Verificada la información que los contrayentes han alcanzado a la autoridad eclesiástica para anexarla a su expediente matrimonial, se procedió a dar la autorización, fechada el 7 de marzo de 1837, en la que se indicaba, según firma y rúbrica José (H)erazo, que no había impedimento para las nupcias de los solicitantes. En tal sentido:

Recíbase a esta parte la información de soltería que ofrece, tómese a los contrayentes el consentimiento secreta y apartadamente, líbrese la licencia en la forma ordinaria sometida a qualquiera (sic) de los curas rectores de la

comunicación periodística acerca del fallecimiento de Dominga Soriano de Palma en El Comercio de Lima (a partir del 10-XII-1863 y ed. ss.), el expediente matrimonial de Pedro Palma y Dominga Soriano (1837); y la lista del vecindario de la Casa de Leuro que habitó en la calle del Rastro de San Francisco en el centro de la capital (1939) (Holguín, 1994, p. 50). 
Parroquia del Sagrario para que procediendo las tres proclamas que dispone el Santo Concilio de Trento, no resultando impedimento, case y vele según el orden de Nuestra Santa Madre Yglesia (sic) a los contenidos de este pedimento. (Ibíd., p. 308).

Finalmente, otro texto inserto en el mismo expediente matrimonial confirma la filiación o nexo sanguíneo que existía realmente entre la abuela y la madre del tradicionista; ambas, como se ha mencionado líneas arriba, eran descendientes de la raza negra:

Doy fe que Guillerma Santa María Madre que dijo ser de Dominga Soriano me expuso que era gustosa en que la citada su hija se case con Pedro Palma y no firmó por no saber. Fecha ut supra. Ante mí. Manuel Lazo [Firmado y rubricado]. (Loc. cit.).

\section{Ser de la negritud era un estigma}

Ser de raza negra o descendiente de ella ha sido en el Perú desde el siglo XVI una carga de oprobio muy dolorosa o "signo de infamia" 16 para muchas generaciones de personas de color, salvo en los casos en que el tono de su piel y sus rasgos físicos no los delataban a simple vista ${ }^{17}$. Y hoy, inclusive, con todo lo

16 Según informa Héctor López Martínez, este es uno de los calificativos más duros con los que la sociedad peruana estigmatizaba a la negritud aún en la época decimonónica (1993, pp. 12 y 29).

17 Con esto no quiere decirse que no hubiera negros o descendientes de ellos que lucharon socialmente por ganarse una posición en la capital peruana, el caso más emblemático sea quizá el de José Manuel Valdés Cabada, notable protomédico que ejerció a fines del siglo XVIII y principios del XIX. Su inteligencia, constancia y espíritu de servicio a los demás le granjeó la estima de la sociedad de su tiempo, a tal punto que el rey Carlos IV le permitió obtener el grado de Doctor en la Real y Pontificia Universidad de San Marcos de Lima (López, 1993, p. 31). Otro caso digno de mención es el del acuarelista Francisco 
que el mundo ha avanzado en materia de derechos humanos y reivindicaciones sociales, subsisten en la sociedad peruana remanentes muy fuertes de este tipo de discriminación racial. Ello vendría a justificar en gran medida que Ricardo Palma, quien desde muy joven deseó hacerse de un nombre de prestigio en el mundo de las letras y escalar una posición social expectante en la capital peruana, no admitiera abiertamente su ligazón con la negritud. Aunque no siempre pudo librarse de los ataques o insultos que algunos de sus enemigos le profirieron en persona o mediante la prensa escrita. Tal es el caso del texto aparecido en el diario La Sabatina el 28 de diciembre de 1872 con el título "Historia Antigua I", firmado con el seudónimo de Diabolaccio. Seudónimo este que correspondía al director de la publicación satírica, Luis Enrique Márquez. Al respecto, puede leerse:

Luis Enrique Márquez (1846-1888), hermano del "bohemio" José Arnaldo y director de esta revista satíricopolítica, pudo ser Diabolaccio y haber recibido la información sobre doña Guillerma de aquel, compañero de Palma en los primeros pasos literarios. No fue la única vez que La Sabatina se ocupó de la señora, de su color negro y de su nieto, y al hacerlo le otorgó la condición de criada de un cura Solar (Holguín, 1994, pp. 50-51, negritas nuestras).

Otros ejemplos que bien pueden traerse a colación, son los casos de los insultos o diatribas que algunos escritores extranjeros, contemporáneos o no al tradicionista, publicaron contra su madre en otras latitudes. Este es el caso del escritor venezolano Rufino Blanco Fombona, quien en cierta oportunidad se refirió a la progenitora de Palma haciéndola parte de una infeliz historia:

Fierro, más conocido en la Lima del 800 como "Pancho Fierro", mulato que la sociedad limeña reconoció y valoró por su arte pictórico de costumbres (Barrón, 2018, p. 49). 
Rufino Blanco Fombona (1874-1944), informado torcidamente por Manuel Gonzáles Prada (1844-1918), anotó en 1915 que Palma era fruto de la violencia sufrida por una pobre y honesta mujer, en los suburbios de Lima, de parte de un negro caribeño llegado al Perú en los ejércitos de la Gran Colombia al mando de Bolívar; así quiso vengar cierto comentario en su contra escrito por Palma (Ibíd., p. 22, negritas nuestras).

Este tipo de ataques directos y otros sutiles que soportó a lo largo de su vida ${ }^{18}$ llevaron al tradicionista a adoptar una posición de reserva sobre su condición afrodescendiente que le venía por su sangre materna. Esta especie de "autoblanqueamiento" o "silencio deliberado", que algunos biógrafos admiradores de la obra de Palma compartieron también en su momento, ha sido criticado severísimamente sobre todo por algunos estudiosos actuales de la negritud, quienes juzgan, al parecer, con patrones del presente hechos del pasado, sin comprender el contexto histórico y social que le tocó vivir al personaje, amén de otras razones nacidas en el fuero interno del escritor que es difícil conocer a cabalidad. En esta línea crítica inflexible se inscribe, por ejemplo, el sanmarquino Julio Díaz Falconí, cuando dice:

Ricardo Palma renegó de su madre porque era negra. Escribió miles de carillas, pero en ninguna de ellas aparece el nombre de doña Dominga Soriano [...].

En 1933 Angélica Palma [...] y Raúl Porras Barrenechea (1934) utilizaron el mismo procedimiento. Le ocultaron

18 Algunos de los ataques racistas que tuvo que soportar Ricardo Palma están recogidos en la prensa escrita limeña de la segunda mitad del siglo XIX. De tal modo que, en diarios como El Comercio, La Campana, La Sabatina, entre otros, se puede hallar buenos ejemplos de ello. Debe expresarse en honor a la verdad que Palma no era del todo un santo varón, seguramente habría dado más de una vez motivo o causado molestia a otros con su estilo satírico, mordaz e incisivo (Holguín, 2001, pp. 129-130). 
la verdad a la sociedad racista del Perú, porque no podían aceptar que el más popular escritor limeño fuera afroperuano. Y se pusieron de acuerdo para afirmar que la madre de Ricardo Palma murió siendo este "aún muy pequeño" (2007, pp. 15-16, negritas nuestras).

Oswaldo Holguín, al dar una opinión más sopesada sobre la postura adoptada por el tradicionista respecto a su ascendencia negra, llega a esta afirmación:

Palma no negó su ancestro negro, pero, como muchos peruanos tampoco lo hizo público, pues reconocer una ascendencia tan poco valorada en su época no sólo podía ser visto con escándalo sino interpretarse como señal de desafío a la sociedad (2001, p. 142, negritas nuestras).

Si bien, por una parte, en términos actuales podría registrarse el nombre de Ricardo Palma como un escritor afrodescendiente, la verdad es que, por otra parte, no podría considerársele como tal. Para ser un afrodescendiente real o auténtico no solo interesa portar la herencia de los genes de la raza negra, es también necesario que la persona se acepte como tal en su "yo interior", en el hondo de su espíritu, esto es, que sea plenamente consciente de que tiene esa condición; y, además, debe manifestarla sin reservas de modo público, que es lo mismo decir "pregonarlo a los cuatro vientos" como una muestra de orgullo, como un timbre de grandeza. Así como cuando el Inca Garcilaso de la Vega tuvo el orgullo de llamarse a sí mismo mestizo en una época en que decirlo podía acarrearle el desprecio de los demás. Al respecto, se lee en los Comentarios Reales (Parte I, libro IX, cap. XXXI):

A los hijos de español y de india, o de indio y española, nos llaman mestizos, por decir que somos mezclados de ambas naciones; fue impuesto por los primeros españoles que tuvieron hijos en Indias; y por ser nombre impuesto 
por nuestros padres y por su significación, me lo llamo yo a boca llena y me honro con él. Aunque en Indias si a uno de ellos le dicen sois un mestizo, lo toman por menosprecio (2007, p. 856).

\section{¿Contribuyó Palma con las Tradiciones peruanas a denunciar la injusticia social que vivió en el pasado la negritud?}

La injusticia que se da en las relaciones sociales de poder ${ }^{19}$ es, en realidad, un tema de interés sociológico de nuestro tiempo, y no un asunto que corresponda propiamente a la época en que vivió Ricardo Palma (1833-1919). Y esto no porque los problemas sociales que vivían los estratos oprimidos o de baja estofa como solía llamárselos, esto es, negros, mulatos, zambos, indios, cholos, chinos, etc., hubieran desaparecido del todo, sino porque en el Perú de la época el interés de escribir sobre estos asuntos era inusual y hasta de mal gusto, y los pocos escritores que trataron temas de reivindicaciones sociales no poseían en su discurso los niveles de argumentación intelectual ni los medios de impacto con los que hoy se cuenta para remover las bases mismas de la sociedad y, por tanto, lograr los cambios radicales y efectivos que se anhelan dentro de una sociedad más justa y democrática.

La importancia que Palma otorga al tema de "lo negro" y "la negritud" no es asunto de poca monta. Por ello su presencia es recurrente en diversos relatos, aunque estos lleguen a nosotros a

19 Las relaciones sociales de poder son una multitud de interacciones, reguladas por normas sociales, entre dos o más personas. Se piensa en el poder no como un objeto que alguien posee y otros desposeen o que esté localizado en los aparatos del Estado, sino desde una perspectiva relacional con una trama más compleja. Vid. Relación de Poder en: https://es.wikipedia.org/wiki/Relaci\%C3\%B3n_de_ poder. 
través de un género narrativo en donde los episodios históricos están activados por la ficción literaria. Como bien se sabe, "Palma no fue un historiador en el sentido erudito que desempolva documentos, pero en cambio, hizo tarea de mayor alcance [en el] arte, pues los utiliza para proveerse de imágenes y datos y transfigurarlos ingeniosamente" (Núñez, 1998, pp. IX-X). Este y no otro fue el medio que el tradicionista escogió para hacernos conocer el pasado de la época virreinal y el de los albores de la República. Además, no debe olvidarse que el fin esencial de la obra palmina, más que tener un carácter sociológico o histórico, tuvo carácter literario, vale decir, estético (Compton, 2000 , p. 7). Confundir este fin, lleva a algunos estudiosos a caer en el error de que a Palma le faltó coraje para denunciar e incidir mucho más en los problemas de injusticia social que vivió la negritud en el pasado. Y no por haber escogido este derrotero puede decirse tampoco que el tradicionista ayudó a ocultar las injusticias que se cometieron en contra de ella a lo largo de casi trescientos años de dominio español. En esta línea de pensamiento errado parece inscribirse, por ejemplo, Heidi Carolyn Feldman cuando expresa:

En las descripciones que hace Palma de la vieja Lima no se dan detalles de las relaciones de poder, y a los negros se les dota de una perspectiva histórica como parte del paisaje colonial (fantasiosos vendedores ambulantes, esclavos felices...). Igual que las tradiciones de Palma, el renacimiento afroperuano representó e imaginó escenas del pasado (los tiempos de la esclavitud y de la "vieja Lima") en contraste con el enfoque presentista del típico costumbrismo latinoamericano. Este énfasis en el pasado permitió reforzar la idea de que los negros peruanos contribuyeron a la formación de la cultura criolla de la costa, al darle vida al tipo de tradiciones fantasiosas imaginadas por Palma como una nostalgia criolla, y al dejar intacta en gran medida la 
noción de que los negros y su cultura desaparecieron o fueron asimilados por la cultura criolla poco después de la abolición de la esclavitud. Cuando se bajaban las cortinas, los blancos criollos regresaban a sus vidas modernas en las que los negros peruanos seguían siendo invisibles (2017, p. 207).

Finalmente, debe indicarse que la posición de Ricardo Palma frente al tema de la esclavitud negra no es la de una persona indiferente o frívola, por el contrario, se conduele profundamente ante el maltrato, el dolor y la injusticia que, por muchos siglos, reinó en la vida de los hijos del continente africano y sus descendientes. "Lo negro" y "la negritud", muy aparte del fin literario que lo animó a incluir estos temas dentro de sus Tradiciones, según él mismo lo expresa en "El Rey del Monte", merecen contarse con la mayor seriedad y mesura. Sobre el particular, se lee:

Con el cristianismo, que es fraternidad, nos vino la civilización de Europa, y como una negación de la doctrina religiosa, la trata de esclavos. Los cuales expedientes de que se valían los traficantes en carne humana para completar en las costas de Arica el cargamento de sus buques, y la manera bárbara como después eran tratados los infelices negros no son asuntos para artículos del carácter ligero de mis Tradiciones (1957, p. 903).

\section{¿Son las Tradiciones peruanas fruto único de lo negro en Palma?}

Afirmar que la obra monumental de Palma -las Tradiciones peruanas- es fruto único de la impronta biológica y de los rasgos psicológicos negros que subyacen en su carácter y personalidad se constituye, a todas luces, en un aserto aventurado y poco 
serio. Y esto por un principio básico, no se olvide que en el mestizaje peruano, en cada ser, convergen o "viven" muchas razas (blanca, india, negra, etc.); y el tradicionista, como hombre mestizo que era, no es ajeno a esa realidad, por tanto, los aportes biológicos y psicológicos recibidos por cada una de esas razas son difíciles de precisar en él y, por ende, en su obra escrita. Sin embargo, Holguín nos da un derrotero cuando dice:

Lo negro en el carácter y personalidad de Palma debe encontrarse en aspectos de la comunicación -locuacidad, gracejo, etc.- aunque sin cerrar la puerta a otra parentela. En realidad, aunque es un asunto cuya última palabra quizá no se pueda decir, debo recordar cómo en más de un escrito Palma emplea altas dosis de facundia, lisura y audacia propias de un espíritu retozón e iconoclasta, tanto como de zumba, burla y sátira normales en el que ve la vida en forma ligera y sin complicaciones, todo ello sin desmedro del empleo de diálogos que transparentan un lenguaje popular presto a la defensa y al ataque [...]. Que todo ello sólo sea producto de la influencia negra en la sociedad criolla, sin duda es discutible, no lo es en cambio que remita, entre otros abrevaderos, a la fuente africana (2001, p. 139).

\section{Principales Tradiciones peruanas que nos hablan de lo negro y la negritud}

De acuerdo con una lectura general de las Tradiciones peruanas existen más de una veintena de narraciones en donde se pueden encontrar elementos que hacen referencia a "lo negro" y a "la negritud" en el corpus palmino; sin embargo, si hablamos de personajes específicos, acontecimientos históricos o referencias de mayor envergadura donde se puede apreciar de un modo más claro la presencia de la raza negra, los rasgos de su carácter o las manifestaciones culturales que la distinguen, tenemos las siguientes narraciones: 


\section{"Los ratones de fray Martín"}

Hablando, por ejemplo, de fray Martín de Porres, don Ricardo Palma tipifica muy bien la condición sanguínea de "mulato" que dicho bienaventurado poseía racialmente cuando nos recuerda a sus progenitores: un blanco y una negra (Juan de Porras y Ana Velásquez $)^{20}$ :

"Nació este santo varón en Lima el 9 de diciembre de 1579 y fue hijo natural del español don Juan de Porres (sic), Caballero de Alcántara, en una esclava panameña" (Palma, 1957, p. 264).

¿Fue este santo varón un mulato analfabeto más de los que había en la Ciudad de los Reyes? Claro que no, era un negro ladino competente en lengua española. Palma dice sobre el particular:

"Llevólo su padre a Guayaquil, donde en una escuela, cuyo dómine hacía mucho uso de la cáscara de novillo, aprendió a leer y escribir" (Ibíd.).

Recordando el tipo de ocupación u oficio que un negro podía ejercer por sus limitaciones sociales, dice el tradicionista del futuro santo limeño:

Dos o tres años más tarde, su padre regresó con él a Lima y púsolo a aprender el socorrido oficio de barbero o sangrador, en la tienda de un rapista de la calle Malambo.

Mal se avino Martín con la navaja y lanceta, si bien salió diestro en su manejo, y optando por la carrera de santo, que en ese tiempo era una profesión como otra cualquiera,

20 El estudio biográfico que el Dr. José Antonio del Busto consagró a fray Martín de Porras es uno de los que mejor informa sobre la vida de sus padres (v. 2001, pp. 29-43). 
vistió a los veintiún años de edad de lego o donado en el Convento de Santo Domingo (Ibíd.).

\section{"La emplazada"}

El tradicionista nos recuerda de una manera explícita que las haciendas de la costa peruana tenían muchísimos esclavos negros como peones para las labores agrícolas y ganaderas. A mayor o menor cantidad de esclavos, se podía deducir fácilmente cuál era el nivel de riqueza de esos hacendados. En una de estas haciendas costeñas, Palma encuadra su tradición "La emplazada":

[La condesa Verónica Aristizábal] luego de que pasaron los primeros meses de luto y que hubo llenado fórmulas de etiqueta social, abandonó [su] casa de Lima, y fue con baúles y petacas a establecerse en una de sus haciendas. Para que el lector se forme concepto de la importancia del feudo rústico. Nos bastara consignar que el número de esclavos llegaba a mil doscientos (p. 471).

En su hacienda, la joven viuda se enamoró de Pantaleón un esclavo negro que su difunto esposo protegió desde niño, y con el tiempo le hizo aprender el oficio de médico. Mas cuando este conoció a la esclava Gertrudis, la aparente felicidad vino a trocarse en celos devoradores. Celos que vinieron a alimentar un mercedario cizañero que a la hacienda llegaba y que también se enamoró de Gertrudis, pero que esta nunca correspondió.

Verónica, llevada por los celos enfermizos al enterarse de que su amante, el negro Pantaleón, mantenía amoríos con Gertrudis, luego de flagelarlo, lo mandó echar en una paila de miel hirviendo. Muy aparte del final trágico que corrió el tal Pantaleón y de la muerte premonitoria que este le anunció a Verónica, hay un dato interesante sobre una forma en la que 
un esclavo o esclava de aquel tiempo podían llegar a alcanzar la libertad: la voluntad del amo. Al respecto Palma escribe:

Y así llegó la mañana del día en que expiraba el fatal plazo, y iadmirable fenómeno! La condesa amaneció sin delirio. El nuevo capellán que había reemplazado al mercedario fue llamado por ella y le oyó en confesión, perdonándola en nombre de Aquel que es todo misericordia

El sacerdote dio a Gertrudis su carta de libertad y una suma de dinero que le obsequiaba su ama. La pobre mulata, cuya fatal belleza fue la causa de la tragedia, partió una hora después para Lima y tomó el hábito de donada en el monasterio de las clarisas (p. 474).

Otra forma de alcanzar la libertad, la menciona Palma en su tradición "El Rey del Monte", cuando manifiesta:

Andando los años, y con sus ahorrillos y gajes, llegaban muchos esclavos a pagar su carta de libertad y entonces se consagraban al ejercicio de alguna industria, no siendo pocos los que lograron adquirir una decente fortuna ( $p$. 903).

\section{"Brazo de Plata"}

Melchor de Portocarrero Lasso de la Vega, conde de la Monclova, vigésimo quinto virrey del Perú, había perdido un brazo en la batalla de Arrás (que se dio entre España y Francia en 1654), y reemplazó el brazo de carne, músculos y huesos con otro de filigrana de plata, que le servía de prótesis. Era don Melchor muy aficionado al comercio carnal con mulatas, lo cual era moneda corriente entre españoles ricos y los que no lo eran. Don Ricardo Palma refiriéndose a esta predilección de los blancos por las melanodermas dice: 
Fue el caso que, a pesar de sus diciembres, a su excelencia se le encandilaban los ojos que por esas calles tropezaba con una de aquellas hembras, hechas de azúcar y canela, vulgo mulatas, manjar aperitivo para libertinos y hombres gastados.

Las mulatas de Lima eran, como las de La Habana, el non plus ultra del género. [...]. Algún resbalón debió dar su excelencia en amor y campaña con una de esas caritativas vasallas, e hízose pública la largueza del galán en recompensar amorosas complacencias, pues los traviesos limeños le sacaron esta copla que, a guisa de pasquín y escrita con carbón, apareció una mañana en la blanca pared de uno de los pasadizos de palacio:

Al Conde de la Monclova

le dicen mano de plata;

pero tiene mano de oro

cuando corteja mulatas (p. 475)

\section{"Pancho Sales, el verdugo"}

Dice verdad don Ricardo Palma cuando afirma que mejores condiciones de vida tenían los esclavos citadinos respecto a los que vivían en el campo. Esto se manifestaba de muchas maneras, por ejemplo, la ropa que vestían era de mejor calidad y hasta de cierta prestancia.

Al caer la tarde del día 24 de enero de 1765 recorrían las calles de Lima algunos jóvenes pertenecientes a familias aristocráticas, precedidos de un esclavo vestido de librea (...).

El esclavo que acompañaba a cada socio de esa humanitaria cofradía iba con la cabeza descubierta, llevando una salvilla 
o fuente de plata, y en la otra una campanilla del mismo metal, que hacía sonar de rato en rato, pronunciando con clamoroso y pausado acento estas palabras: -iHagan bien para hacer bien por el alma de los que van ajusticiar! (Palma, 1957, p. 747)

Más adelante, Palma señala en esta misma tradición el carácter violento que muchas veces se apoderaba de los negros esclavos, cuando estos eran, sobre todo, acicateados por la violencia con la que se les trataba:

Cinco eran los reos que en esta tarde se hallaban en capilla para ser ajusticiados al siguiente día. Cuatro de ellos eran zarcillos que la horca hacía tiempo reclamaba, pues tenían en la conciencia el fardo de algunas muertes hechas con alevosía y en el despoblado amén de no pocos robos y otros crímenes de entidad. El quinto era un negro esclavo, mocetón de veinte años, zanquilargo y recio de lomos, fuerte como un roble y feo como un pecado mortal. Habiéndose insolentado un día con sus amos, éstos lo mandaron, por vía de corrección al amasijo de la panadería de Santa Ana, cuyo mayordomo gozaba de neroniana reputación. Hacía trabajar a los infelices esclavos que por su cuenta caían con grillete al pie, medio desnudos y descargándoles sobre sus espaldas tan furibundos rebencazos que dejaban impresos en ellas anchos y sanguinolentos surcos. [...].Una noche llegó el esclavo a desesperarse, y en un abrir y cerrar de ojos, lanzándose sobre el mostrador donde lucía el cuchillo con que don Hermenegildo acostumbraba cortar hogazas, lo hundió hasta el mango en el pecho del mayordomo. [...]. Fue muerte muy sentida, y extremada la indignación pública contra el asesino. Pancho Sales, que tal era el nombre de éste, no encontró valedores, y fue condenado a morir en la horca en compañía de los cuatro bandidos (p. 748). 
A través de esta tradición y otras, Palma informa a sus lectores que los negros en la época virreinal no solo tenían la obligación de encargarse de los oficios menores, esto es, ser artesanos (sastres, latoneros, herreros, carpinteros, veleros, olleros, etc.), albañiles o peones; además, debían también asumir las tareas domésticas, que implicaban contacto con la suciedad y malos olores (Arrelucea, 2006, p. 177-178), así como los oficios ingratos que los españoles rehusaban ejercer, como el de verdugo. Uno de los más famosos verdugos de Lima en el siglo XVIII fue Grano de Oro. Palma dice de él:

Grano de Oro era un negrito casi enano, regordete y patizambo, gran bebedor e insigne guitarrista. Habiendo en cierta ocasión sorprendido a su coima en flagrante gatuperio, cortó por lo sano, plantando a la hembra y al rival tan limpias puñaladas que no tuvieron tiempo de decir ni Jesús, que es bueno. La justicia le puso entre la espada y la pared. Obligándolo a escoger entre la horca y el empleo de verdugo, vacante a la sazón (pp. 749-750).

¿Cómo surge la idea de convertir al criminal Pedro Sales en verdugo? Sucedió que antes de ajusticiar a los cinco bandidos, Grano de Oro se emborrachó tanto que cayó muerto al pie de una botija de guarapo: Palma cuenta más de este suceso:

La repentina muerte del verdugo trajo gran agitación entre los golillas. No había quien quisiese reemplazarlo y los reos llevaban trazas de pudrirse en la cárcel. Por fin, sus señorías resolvieron, como último expediente, ver si alguno de los condenados consentía en ajusticiar a sus compañeros y salvar la vida aceptando como titular el aperreado cargo (p. 750). 
Pedro Sales aceptó el reto de las autoridades, y por muchos años más ejerció el oficio de verdugo en la cárcel limeña, hasta que llegó el día de su cesantía y se retiró a vivir en su corral del cuartel quinto del Rímac. El tradicionista cuenta al respecto:

Desde 1824 Pancho Sales quedó cesante; le fue retirada la pensión de diez pesos que recibía por el Cajón de Ribera. Hasta su muerte, después de 1840, habitó una tienda con un gran corral, inmediata a la conocida huerta de Presa, en la Parroquia de San Lázaro (pp. 750-751).

\section{"El Rey del Monte"}

Palma señala en esta tradición que hay una diferencia entre el esclavo del campo y el de la ciudad:

El esclavo que trabajaba en el campo vivía permanentemente amagado del látigo y el grillete, y el que lograba la buena suerte de residir en la ciudad tenía también, como otra espada de Damocles, suspendida sobre la cabeza, la amenaza de que, al primer renuncio, se abrirían para él las puertas de hierro de un amasijo (p. 903).

La marca de posesión que los amos blancos dejaban sobre la piel de los esclavos era la cruel carimba o calimba, en razón de que los esclavos no tenían derechos, pues no eran considerados seres humanos, sino "cosas" u "objetos" (en el sentido jurídico de res). Sobre este punto, Palma manifiesta:

Muchos amos cometían la atrocidad de carimbar o poner marca sobre la piel de los negros, como se practica actualmente con el ganado vacuno o caballar, hasta que vino de España real cédula prohibiendo la carimba (p. 903). 
Había en los amos de los esclavos negros la obligación de cristianizarlos, así lo señala el tradicionista cuando dice:

En el siglo anterior [siglo XIX] empezó a ser menos ruda la existencia de los esclavos. Los africanos, que por aquel tiempo se vendían en el Perú a precio más o menos igual al que se pagaba por la contrata de un colono asiático, merecieron de sus amos la gracia de que, después de cristianados, pudieran, según sus respectivas nacionalidades o tribus, asociarse en cofradías. Aun creemos que vino de España una real cédula sobre el particular (p. 903).

En efecto, las cofradías fueron para los esclavos negros una forma efectiva de conseguir recursos económicos para su subsistencia y otras empresas en las que quisieran embarcarse en pro de su futuro. Sobre esto Palma relata:

muchas de las asociaciones de negros llegaron a poner su tesorería en situación holgada. Los angolas, caravelís, mozambiques, congos, chalas y terranovas compraron solares en las calles extremas de la ciudad, y edificaron las casas llamadas de cofradías. En festividades determinadas, y con venia de sus amos, se reunían allí para celebrar jolgorios y comelonas a la usanza de los países nativos.

Estando todos bautizados, eligieron por patrona de la cofradía a la Virgen del Rosario, y era de ver el boato que desplegaban para la fiesta. [...].

Aunque con menos lujo, concurrían las cofradías a las fiestas de San Benito y Nuestra Señora de la Luz, en el templo de San Francisco y a las procesiones de corpus y Cuasimodo. En estas últimas eran africanos los que formaban las cuadrillas de diablos danzantes que acompañaban a los tarasca, papahuevos y gigantones (pp. 903-904). 
Otro asunto que es tratado en esta tradición de "El Rey del Monte" refiere a un problema social de seguridad ciudadana: el bandolerismo que los negros propiciaban al no haber mucho control de parte de las autoridades locales. Uno de los casos más emblemáticos está aquí narrado con bastante detalle. El personaje es un salteador que robaba a los ricos para darles a los pobres, una especie de Robin Hood (el legendario bandido de las baladas inglesas del siglo XIV). Madre de Rey del Monte, fue Mama Salomé ¿Quién era ella? Palma responde:

La reina de los terranovas, en 1799, era una negra de más de cincuenta inviernos, [...] la que, habiendo comprado su libertad, puso una mazamorrería; y el hecho es que cundiendo la venta del artículo adquirió un fortunón tal que la aclamaron, nemine discrepante, por reina y señora [...].

Como nadie alcanzaba a hacer competencia a la acreditada mazamorrería de mama Salomé, otra del gremio levantó la especie de que la terranova era bruja, y que para hacer apetitoso su manjar meneaba la olla iqué asco! con una canilla de muerto, y canilla de judío, por añadidura.

$[\ldots]$.

Mama Salomé no intentó siquiera una revolucioncilla [...]; se echó a dar y cavar en la ingratitud y felonía de los suyos, y a tal grado se le melancolizó el ánimo, que sin más ni menos se la llevo Pateta [entiéndase la muerte].

Mama Salomé dejaba un hijo, libre como ella y macetón de quince años, el cual juró a sí mismo, para cuando tuviese edad, vengar en la sociedad el ultraje hecho a su madre descorazonándola por bruja y a la vez castigar a los terranovas por la revuelta contra su reina (p. 905). 
Años después el hijo de mama Salomé cumplió su palabra. Capturado y ajusticiado con sus compañeros de delito, fueron sentenciados a morir en la Plaza Mayor, a vista de muchos testigos. Palma cuenta este acontecimiento:

Inmenso era el gentío que ocupaba la Plaza Mayor de Lima en la mañana del 13 de octubre de 1815. Todos querían conocer a un bandido que robaba por amor al arte, repartiendo entre los pobres aquello de que despojaba a los ricos. El Rey del Monte y tres de sus compañeros estaban condenados a la muerte por horca (p. 907).

\section{"Un negro en el sillón presidencial"}

La osadía de un negro bandido, dizque partidario del general Orbegoso, llegó a su culmen cuando se atrevió a sentarse en el solio de la más alta magistratura de la República del Perú. En esta narración, Palma cuenta lo siguiente:

El 23 de febrero de 1835, a los pocos días de ascendido a general de brigada por el presidente Orbegoso, se sublevó en el Callao don Felipe Santiago Salaverry contra el gobierno constitucional [...]. Forzado Salaverry a emprender campaña sobre Arequipa, dejó en Lima con el carácter de prefecto [...] al coronel don José Ángel Bujanda con los cuarenta jinetes a batir una montonera que merodeaba entre Surco y Miraflores, cuando a las doce del día se presentó en Malambo el famoso negro León Escobar, capitán de una cuadrilla de treinta bandidos, los que a todo galope avanzaron desde San Lorenzo hasta la puerta de palacio, en el que la guardia contaba de un solo teniente, un sargento y seis soldados que no opusieron la más leve resistencia. Se constituyó León en el salón de Palacio, estacionándose los montoneros frente al atrio de la catedral y vitoreando estruendosamente a Orbegoso. 
Tres de los ediles, que accidentalmente se encontraban en la Casa Municipal tuvieron el valor cívico de encaminarse a palacio para solicitar del jefe de la montonera el que no consintiese que ésta cometiera extorsiones.

El negro Escobar, arrellanado en el sillón presidencial, les brindó asiento en la que fue sala de ceremonias en tiempo de los virreyes, y los trató con cortesía, prometiéndoles que no autorizaría el menor desmán, siempre que la Municipalidad, de la que aquellos señores investían el carácter de personeros, se aviniese a pagar un cupo de dinero que necesitaban para atender a las exigencias y manutención de su gente [...].

Poco después de las tres de la tarde y dando entusiastas vivas al caudillo, abandonó la montonera nuestra capital (pp. 1075-1076).

\section{"Un asesinato justificado"}

Las mujeres de raza negra, y muy particularmente las mulatas, por la voluptuosidad o sensualidad que les acompañaba de modo natural, han sido en el pasado, lo son en el presente y lo seguirán siendo en el futuro, objeto de atención masculina. Las esclavas negras eran vistas por los hombres como sensuales, libertinas, dispuestas al sexo y al placer, por lo tanto, carentes de honor (Arrelucea, 2006, p. 179). Esta característica no pasa inadvertida para la pluma pícara del tradicionista. Justamente en la tradición "Un asesinato justificado" queda este asunto de manifiesto:

Alcalde de Corte en 1752 era el licenciado don Gonzalo de Vallés. Una mañana encaminándose a la cárcel de la Pescadería para despachar, con destino al presidio de Chagres [en el Caribe panameño], a tres condenados a expiar allí sus delitos durante ocho años, [ocurrió que] despidiéndose de uno de los reos, sentenciado por ladrón y asesino, hallábase 
su hermana, una bellísima mulata, la que se arrojó a los pies de don Gonzalo pidiéndole la libertad del pez. El demonio de la lujuria mordió los sentidos del licenciado, y a trueque de los apetitosos favores de la muchacha convino en sacrificar sus deberes de juez y su conciencia de hombre (p. 640).

\section{"Los aguadores de Lima"}

Dentro de las ocupaciones $\mathrm{u}$ oficios menores que los negros de la Ciudad de los Reyes como parte de su actividad rutinaria debían llevar a cabo, Palma destaca la labor que realizaban los aguadores desde 1535. Sobre el particular, expresa:

Cuando fundó Pizarro la ciudad, tenían los vecinos que ocupar un doméstico para que, en grandes cántaros de barro, trajese del río al hogar el refrigerante líquido. Tan luego como la trata de negros se generalizó, las personas acomodadas quisieron consumir mejor agua que la del cauce del río, y mandaban un esclavo, caballero en un asno, que sustentaba un par de pipas, a proveerse de agua clarísima de Piedra Lisa y de otras vertientes vecinas a la ciudad (p. 391).

Palma indica, además, que estos aguadores se caracterizaban por poseer un léxico bastante florido o lleno de palabras procaces o coprolálicas:

Desde los primeros tiempos se singularizaron los aguadores por la desvergüenza de su vocabulario, tanto que era como refrán para las buenas madres limeñas el responder a sus hijos diciendo: callen niños, que por las lisuras que dicen me parecen aguadores (Ibíd.).

Los aguadores negros añadían a sus labores propias de llevar y traer el líquido elemento para la subsistencia de las familias, otra menos grata que las autoridades virreinales les asignaron 
obligatoriamente: eliminar a los canes callejeros que deambulaban por la urbe limense. Al respecto, el tradicionista cuenta:

Los del ambulante gremio [los aguadores] se anunciaban con el tintineo de una campanita que sonaba a cada paso del asno, y conforme a su pragmática o reglamento estaban obligados a consagrar quincenalmente una tarea de matanza de perros callejeros que no ostentaran un collarín, obtenido por los dueños de la autoridad de la policía, previo pago de dos pesos. Barato era el seguro de vida, siendo el mes de diciembre el signado para renovación de la póliza, digo, argolla (Ibíd.).

\section{"El sombrero del padre Abregú"}

En las primeras décadas de la República famosos fueron a las afueras de la muralla de Lima los negros salteadores de caminos, que en conjunto solían formar montoneras en los descampados. Con este antecedente, don Ricardo Palma crea la tradición que tiene como personaje principal al padre Abregú, un sacerdote de la Congregación de San Felipe Neri, quien, al igual que otros sacerdotes que salían de la ciudad para celebrar misa en otros pueblos cercanos, vestía decentemente con poncho de balandrán y sombrero de jipijapa más o menos guarapón, montado sobre una recia mula ${ }^{21}$. Sin embargo, en cierta ocasión fue asaltado por un conjunto de negros bandoleros, que lo obligarían desde entonces a usar sombrero de teja y una mula tísica, como "santo y seña", para no ser asaltado en el recorrido que usualmente hacía entre Lima y el Barranco.

21 Puede verse la imagen del padre Abregú en una de las famosas acuarelas de Pancho Fierro, dentro de la colección que perteneció a Ricardo Palma y que hoy posee la Municipalidad Metropolitana de Lima (Stasny, 2007, p. 195). 
Cuando el general Salaverry, allá por los años de 1835, se alzó con el santo y la limosna, pasó Lima por conflictos tales que hubo día en que se vió la capital como moro sin señor; y hasta un jefe de montoneros, el negro León [Escobar], se posesionó del Palacio [...] y aunque sólo por un día, gobernó como cualquier mandarín de piel blanca. Es decir, que dio un puntapié a la Constitución y que hizo alcaldada y media.

Con la mascarilla de partidarios de una causa política, los bandidos ejecutaban mil fechorías y estaban esos caminos intransitables para la gente pacata y honrada. Agustín el Largo, Portocarrero el Corcovado y demás jefes de montoneros eran los hombres de la situación. Como hoy se dice. Historias de robos, asesinatos y otros estropicios en despoblado eran la comidilla diaria de la conversación entre los vecinos de la capital, que no se atrevían a salir fuera de murallas sin previo acto de contrición, ya que no oleados y sacramentados (Palma, 1957, p. 1071).

\section{“iPues bonita soy yo, la Castellanos!”}

En esta tradición don Ricardo Palma cuenta que en tiempos del trigésimo tercer Virrey del Perú, el catalán don Manuel Amat y Junyent, hubo en Lima dos damas que pugnaron por ganar celebridad: la una era la criolla Micaela Villegas y Hurtado de Mendoza, conocida por su hipocorístico de "Mica" Villegas, y la otra era la mulata María Castellanos, llamada por su entorno más cercano como "Maruja", "Marujita" o "Mariquita" Castellanos. ¿Qué dice de ellas el tradicionista?:

Mica Villegas era una actriz del teatro de Lima, quebradero de cabeza del excelentísimo señor virrey de estos reinos del Perú por S.M. Carlos III, y a quien su esclarecido amante, que no podía sentar plaza de académico por su corrección en eso de pronunciar la lengua de Castilla, apostrofaba en 
los ratos de enojo, frecuentes entre los que bien se quieren, llamándola Perricholi [...]. María Castellanos, como he tenido el gusto de decirlo, era la más linda morenita limeña que ha calzado zapatitos de cuatro puntos y medio.

Como una y una son dos

por las morenas me muero

lo blanco, lo hizo platero;

lo moreno, lo hizo Dios (pp. 650-651).

\section{¿De qué modo pugnaron estas dos hijas de Venus? Palma responde:}

La Villegas quiso humillar a las damas de la aristocracia, ostentando sus equívocos hechizos en un carruaje y en el paseo público. La nobleza toda se escandalizó y arremolinó contra el Virrey. Pero la cómica, que había satisfecho su vanidad y capricho, obsequió el carruaje a la parroquia de San Lázaro para que en él saliese el párroco conduciendo el Viático (p. 651).

Por su parte, la Castellanos, no queriendo quedarse a la zaga, tomó de inmediato acción:

Era moda que toda mujer que algo valía tuviese predilección por un [perrito] faldero. El de Marujita era un animalito muy mono, un verdadero dije. Llegó a la sazón la fiesta del Rosario y asistió a ella la querida del conde muy pobremente vestida, y llevando tras de sí una criada que conducía en brazos al chuchito. Ello, dirás lector, que nada tenía de maravilloso; pero es que el faldero traía un collarín de oro macizo con brillantes como garbanzos.

[...] Terminada la procesión se supo que Cupido [que así se llamaba el perrito], con todos sus valiosos adornos, había sido obsequiado por su ama a uno de los hospitales de la 
ciudad, que por falta de rentas estaba poco menos que al cerrarse.

La Mariquita ganó desde ese instante, en la simpatía del pueblo y de la aristocracia, todo lo que había perdido su orgullosa rival Mica Villegas; y es fama que siempre que hablaba de este suceso, decía con énfasis, aludiendo a que ninguna otra mujer de su estofa la excedería en arrogancia y lujo: iPues no faltaba más! iBonita soy yo, la Castellanos! (p. 652).

\section{"Los repulgos de San Benito"}

Muchísimos años antes de que fray Martín de Porres subiera a los altares, había en la Lima virreinal devoción por otro santo negro llamado San Benito de Palermo, considerado hoy por los afroamericanos como su santo patrón y cuya fiesta canónica se celebra el 4 de abril. San Benito de Palermo es también conocido como San Benito o Benedicto el Africano, el Moro o el Negro. Este monje italiano nació en Sicilia en el año 1524, en las proximidades de Mesina, en San Filadelfio, por lo que a veces se le llama también San Benito de San Filadelfio.

A los 20 años de edad conoció a un grupo de ermitaños de la Orden de San Francisco de Asís a los que se unió espiritualmente, no obstante, en 1564 el grupo se disolvió y Benito ingresó en el convento de Santa María de Palermo, donde debido a su condición de analfabeto fue inicialmente destinado a la cocina del convento. A pesar de ello, su piedad, su humildad y los milagros que se le atribuyeron, sobre todo sanación de enfermos, le dieron gran fama. Su óbito ocurrió en el año 1589 en la ciudad de Palermo ${ }^{22}$.

22 Esta información puede ampliarse en https://www.ecured.cu/San_Benito_de_ Palermo. 
Su devoción la trajo al Perú la Orden seráfica, por ese motivo había una imagen de él en uno de los altares laterales de la iglesia grande de San Francisco de Lima. Es importante relievar que cuando el tradicionista fue niño, su casa era vecina a dicha iglesia, pues, como se sabe, vivió en la calle del Rastro de San Francisco (Holguín, 1994, p. 75). Esta es la razón quizá por la cual don Ricardo Palma llegó a incluir en una de sus tradiciones a este santo varón como un personaje estatuario que recordaba de su niñez, aunque, como él mismo declara, no conocía bien su biografía. Al respecto dice:

Los pocos mataperros de 1845 que aún comen pan en esta metrópoli limeña recordarán al hermano Piojo Blanco, lego profeso del convento de San Francisco. Me parece que lo estoy viendo en pleno ejercicio de sus funciones de cuidador o sacristán del altar de San Benito, santo del que era gran devoto.

El buen lego se había familiarizado tanto con San Benito, que cuando empleaba el plumero para sacudir el polvo del altar lo hacía platicando con la efigie; y tan grande era su alucinación, que afirmaba formalmente que el santo le correspondía y que, en conversación íntima, lo había puesto al corriente en las cosas de la otra vida.

Yo no sé por qué (no he tenido un cuarto de hora ocioso para leer la vida del santo) exhiben en los altares al bienaventurado italiano con rostro y manos de negro retinto. Sospecho que será por encomiar en él la virtud de la humildad; y si no estoy en lo cierto, que no valga (p. 1112). 


\section{"La Conga"}

En una de las llamadas reminiscencias personales de don Ricardo Palma ${ }^{23}$ que aparecen en la Tradiciones peruanas, más que hacer mención a un personaje o héroe en particular, el asunto central es una composición musical de ascendencia u origen negro, llamada La Conga ${ }^{24}$. Según esta tradición, allá por diciembre de 1867, el coronel José Balta y Montero estando en el departamento de Lambayeque combatiendo a las huestes del presidente Mariano Ignacio Prado, diose una situación muy curiosa con respecto a dicha composición criolla, pues inicialmente la cantó y bailó la negritud de esa zona geográfica (quizá negros asentados en el pueblo de Saña) y, finalmente, todos los chiclayanos la hicieron suya la noche del 6 de enero de 1868, noche en la que los rebeldes de Balta vencieron definitivamente a los soldados del gobierno, y tal cual como los revolucionarios franceses cantaron y bailaron la Marsellesa al tomar la Bastilla. De acuerdo con lo que recoge Fernando Romero Pintado (en base a una tradición de Nicanor de la Fuente "Nixa"), el origen de La Conga sería este:

Al encenderse en el Perú la primera guerra civil que provocó la caída del gobierno de Prado, se dio en el Norte una batalla que en los iniciales días de diciembre de 1867 aseguró la victoria del caudillo local. Es bien conocido que el triunfo se atribuyó al efecto de una conga creada al momento por la muy mayoritaria población afronegra de esa zona

23 No se olvide que en su juventud el tradicionista fue secretario particular del coronel José Balta, y acompañó a este político en sus andanzas revolucionarias por el norte peruano. Más tarde, el jefe de Estado lo recompensaría, al parecer, con una diputación y luego con una senaduría por la provincia litoral de Loreto (Oviedo, 1965, p. 78).

24 Un interesante estudio lexicográfico de la voz “conga” en el ámbito negro latinoamericano ha sido realizado por don Fernando Ortiz (1950, pp. 78-86). Asimismo, véase el aporte de Fernando Romero (1988, pp. 83-85). 
geográfica, que fue compuesta por el jaranista chiclayano Juyupe, bailada por primera vez por la negra Nevao, la mama Jacoba, la Pitonga y la ñata Fidela (1988, p. 83).

\section{"Manumisión"}

Si bien son casi una docena los relatos que el tradicionista redactó para dedicarle a personajes y asuntos vinculados a lo negro y la negritud, es quizá el informe histórico titulado "Manumisión" el que de modo más serio y extenso trata estos temas. Según expresa el propio Palma, compuso este texto (fechado en 1888) por pedido expreso del gobierno del Perú, que a su vez había sido requerido por el gobierno del Brasil como una especie de antecedente para realizar una reforma similar en el campo social. Palma se remontó a los días de la Conquista para empezar su informe, y llegó a extenderse hasta pocos años después del decreto de Huancayo. Sobre el particular, dice:

La introducción de los negros africanos en el Perú se estableció desde los primeros tiempos de la Conquista, fundándose en que los indios mitayos no eran a propósito para tareas muy duras. Así, en 1555, pocos meses antes de la abdicación y retiro al monasterio de Yuste, el emperador Carlos V acordó al ex gobernador Vaca de Castro, en premio de sus servicios a la Corona y como vencedor de la facción almagrista, la licencia para introducir en el Perú 500 piezas de ébano (negros) libres de todo derecho fiscal. En ese año el número de esclavos esparcidos en toda la costa peruana, llegó ya a 1,200. El negro no se aclimató a la frígida serranía (Palma, 1957, p. 138).

Con las luces y las sombras que este asunto arroja a lo largo de casi trescientos años de dominación española, luego de hacer un balance en el que no se puede ocultar el dolor, el abuso, el maltrato de diverso tipo, la injusticia y la muerte. Palma en 
su mencionado informe histórico llega a la época del mariscal Ramón Castilla, el gran libertador de la ominosa condición de esclavos que tuvieron en el Perú los hijos del continente africano. Al respecto, el tradicionista comenta:

En 1854 el gran mariscal Ramón, caudillo de la revolución contra el presidente constitucional don José Rufino Echenique, dictó el 3 de diciembre (y precisamente en Huancayo) un decreto de inmensa importancia social y política, declarando abolida la esclavitud. [...]. Este decreto dictatorial fue motivado por uno que en noviembre había expedido el general Echenique, declarando libres a los negros que se afiliaran en el ejército constitucional (p. 141).

\section{A modo de conclusión}

La presencia de "lo negro" y "la negritud" en las Tradiciones peruanas no es asunto accidental o intrascendente dentro del corpus palmino, y esto porque Palma es consciente de que los hijos del continente africano han jugado un papel importante en la conformación del mestizaje racial y cultural del Perú. $\mathrm{Y}$ esto porque los africanos al llegar a nuestras tierras no vinieron desprovistos de cultura, como muchas veces se ha pensado, pues trajeron consigo un idioma, unas creencias y una tecnología propias, que al mezclarse con lo que encontraron y experimentaron aquí produjeron cosas nuevas que nos han legado y constituyen también parte de nuestra actual cultura. La negritud no ha desaparecido del todo en nuestro país, sigue teniendo vitalidad en los descendientes afroperuanos que viven focalizados o concentrados en algunos pueblos costeños específicos como Saña (Lambayeque), Chincha y Cañete (Ica), Yapatera (Piura), o como parte de la vecindad de algunos distritos limeños o barrios del Perú, en donde se los van aceptando lentamente como parte integrante de esas 
comunidades, aunque la verdad es que la discriminación, el racismo y la violencia que se ejerció sobre ellos en el pasado no ha desaparecido del todo en la actualidad.

Muchas veces nos hemos preguntado de dónde sacaba Ricardo Palma ese ingrediente mágico para atrapar a sus lectores desde el inicio de sus relatos. Creador indiscutible de un género particular llamado tradición, sabía tejer los acontecimientos y los personajes hasta hacerlos verosímiles, sin dejar de acompañarlos de fuertes dosis de facundia, socarronería, zumba, entre otros. En el escritor este proceso de creación quizá no era del todo consciente, simplemente fluía de modo natural en su ser, gracias a la predisposición de los genes negros heredados de Dominga Soriano, su madre. Estos genes negros y los rasgos psicológicos que le caracterizan, aunque no puede afirmarse que sean los únicos que definen su obra, por lo menos permiten vislumbrar que en el padre de las Tradiciones peruanas alcanzaron su más elevado pendón, llevándolo a convertirse no solo en un clásico de la literatura peruana sino también hispanoamericana de finales del siglo XIX y principios del XX.

\section{Bibliografía}

Alcocer Martínez, A. (2004). "Lengua y Sociedad: El que no tiene de inga tiene de mandinga”. En Letras, Año LXXV, N¹07-108, Lima: Universidad Nacional Mayor de San Marcos, pp. 33-46.

Arrelucea Barrantes, M. (2006). "Esclavitud, sexo y seducción en Lima, 1760-1820". En Revista del Archivo General de la Nación № 26, Lima: Ministerio de Justicia, pp. 167-192.

Asociación de Academias de la Lengua Española. (2010). Diccionario de Americanismos. Lima: Santillana Ediciones Generales. 
Benavides, M.; León, J.; Espezúa, L. y Wangeman, A. (2015). Estudio especializado sobre población afroperuana. Lima: Ministerio de Cultura y Grupo de Análisis para el Desarrollo.

Barrón, J. (2018). Pancho Fierro, un cronista de su tiempo. Munilibro $N^{\circ}$ 15. Lima: Municipalidad Metropolitana de Lima.

Busto Duthurburu, J. A. del. (2014). Breve historia de los negros del Perú. Lima: Fondo Editorial del Congreso del Perú.

(2001). San Martín de Porras (Martín de Porras Velásquez). Lima: Fondo Editorial Pontificia Universidad Católica del Perú.

(1993), El mestizaje en el Perú. (Colección Algarrobo №38). Piura: Universidad de Piura.

Caro Baroja, J. (1967). “El mestizaje en el Perú”. En Fanal № 82, vol. XXII, pp. 2-8. Lima: International Petroleum Company, Limited.

Compton, M. (2000). La historicidad de las Tradiciones Peruanas de Ricardo Palma. Lima: Biblioteca Nacional del Perú.

Díaz Falconí, J. (1991). Tradiciones olvidadas de Palma. Huancayo: Universidad del Centro del Perú.

. (2007). Los padrinazgos de Ricardo Palma. Trujillo: Papel de Viento Editores.

(2015). Tradiciones peruanas. Tradiciones olvidadas. T. I. Vol. VII. Lima: Editorial Universitaria de la Universidad Ricardo Palma.

Feldman, H. C. (2017). "Escenificando la negritud en la Lima de mediados de siglo XX: las compañías Pancho Fierro y Cumanana". En Lima siglo XX. Cultura, socialización y cambio. Carlos Aguirre y Aldo Panfichi, editores. Lima: Fondo Editorial Pontificia Universidad Católica del Perú. 
Garcilaso de la Vega, I. (2007). Comentarios Reales de los Incas. (En base a la edición de 1609). Lima: Fondo Editorial de la Universidad Inca Garcilaso de la Vega.

Harth-Terré, E. Negros e indios. Un estamento social ignorado del Perú colonial. Lima: Librería Editorial Juan Mejía Baca.

Herrera Cornejo, H. A. (2007). El genio de "El Murciélago". Manuel Atanasio Fuentes y sus grabados costumbristas de Lima de 1800. Lima: Instituto Fotográfico Eugenio Courret.

Hildebrandt, M. (2001). Léxico de Bolívar. El español de América en el siglo XIX. Lima: Edición particular Martha Hildebrandt.

Holguín Callo, O. (1994). Tiempos de Infancia y Bohemia. Ricardo Palma (1833-1860). Lima: Fondo Editorial de la Pontificia Universidad Católica del Perú.

. (2001). "Ricardo Palma y la cultura negra”. En Páginas sobre Ricardo Palma. Lima: Editorial Universitaria de la Universidad Ricardo Palma.

Kusonoki, R. y Wuffarden, L. E. (ed.). (2016). "Arte y Cultura Visual en el Virreinato". En Arte Colonial. Lima: Museo de Arte de Lima (MALI).

López Martínez, H. (1993). El protomédico José Manuel Valdés. Lima: Fondo de Publicaciones de la Dirección de Intereses Marítimos de la Marina de Guerra del Perú.

Mariátegui, J. (1990). África emergente. Lima: Cultura Cuzco Editores.

M'bare N'gom, Felmann, H. C., Campos Dávila, J. et al. (2008). "Escribir" la identidad: creación cultural y negritud en el Perú. Lima: Editorial Universitaria de la Universidad Ricardo Palma.

Mellafe, R. (1964). La esclavitud en Hispanoamérica. Buenos Aires: Eudeba 
Ministerio de Cultura. (2016). Plan Nacional de Desarrollo para la población afroperuana 2016-2020. Lima: Ministerio de Cultura del Perú.

Núñez Hague, E. (1998). Ricardo Palma, escritor continental. Tras las huellas de Palma en Hispanoamérica. Lima: Fondo Editorial del Banco Central de Reserva del Perú.

Ortiz Fernández, F. (1950). La africanía de la música folklórica de Cuba. La Habana: Ministerio de Educación-Dirección de Cultura.

Oviedo, J. M. (1965). Genio y Figura de Ricardo Palma. Biblioteca de América N ${ }^{\circ}$ 5. Buenos Aires: Editorial Universitaria de Buenos Aires.

Palma, C. (1897). El porvenir de las razas en el Perú. Lima: Imprenta Torres Aguirre, Unión 150.

Palma, R. (1957). Tradiciones peruanas completas. Edición y Prólogo de Edith Palma. Madrid: Aguilar.

Peralta Rivera, G. (1990). Los mecanismos del comercio negrero. Lima: Consejo Nacional de Ciencia y Tecnología y Banco Internacional del Perú.

Prince, C. (2011) Lima Antigua. Tipos de Antaño con numerosas viñetas. Edición facsímil de la edición de 1890. Lima: Casa del Libro Viejo.

Quiroz Ávila, R. (2010). La razón racial, Clemente Palma y el racismo a fines del siglo XIX. Lima: Fondo Editorial Universidad Científica del Sur.

Rey Vicente, M. del, Canales Torres, C. (2014). Esclavos. Comercio humano en el Atlántico. Madrid: Edaf.

Rodríguez Pastor, H. (2008). Negritud. Afroperuanos: resistencia y existencia. Serie Mano Negra / 1. Lima: Centro de Desarrollo Étnico (CEDET).

Romero Pintado, F. (1987). El negro en el Perú y su transculturación lingüística. Lima: Editorial Milla Batres.

(1988). Quimba, fa, malambo, ñeque. Afronegrismos en el Perú. Lima: Instituto de Estudios Peruanos. 
Santa Cruz, N. (1988). "El negro en Iberoamérica". En Cuadernos Hispanoamericanos $N^{\circ}$ 451-452. Los Negros en América. Madrid: Instituto de Cooperación Iberoamericana, enero-febrero.

Saponara, M. (2008). Inglaterra y la abolición de la esclavitud en el Perú. Aspectos de política pública 1820-1854. Lima: Fondo Editorial del Congreso del Perú.

Sartre, P. (2015 [1948]). "Orfeo negro". Prólogo a la Anthologie de la nouvelle poésie nègre et malgache de langue française elaborada por Leopoldo Sedar Senghor. París: Presses Universitaires de France (PUF).

Stasny, F. (2007). Acuarelas de Pancho Fierro y seguidores. Lima: Municipalidad Metropolitana de Lima.

Vallejo, M. A. (2013). "Letras afrodescendientes. Apuntes sobre negritud. Reflexiones en torno al desarrollo de la cultura afroamericana, los procesos de su literatura desde la Colonia y la necesidad de visibilizar sus aportes". En Variedades, Semana del 5 al 11 de abril, Lima: Suplemento Cultural de diario El Peruano.

\section{Webgrafía}

Govea, M. y Silva, M. (2018). Reflexiones en torno a la negritud: lucha político-social y reivindicación identitaria. Consultado el 17 de noviembre de 2018 en <http://revele.uncoma.edu.ar/htdoc/revele/index.php/ horizontes/article/view/1808/1878>.Wikipedia.org.

Relación de poder. Consultado el 15 de octubre de 2018 en <http:// es.wikipedia.org/wiki/Relaci\%C3\%B3n_de_poder $>$.Ecured.cu.

San Benito de Palermo. Consultado el 20 de diciembre de 2018 en $<$ http://www.ecured.cu/San_Benito_de_Palermo $>$.

Recibido el 18 de febrero Aceptado el 19 de febrero 